\title{
Article
}

\section{Organizational Ambidexterity and the Emerging-to-Advanced Economy Nexus: Cases from Private Higher Education Operators in the United Kingdom}

Stokes, Peter, Moore, Neil, Smith, Simon Martin, Larson, Mitchell Jonathan and Brindley, Clare

Available at http://clok.uclan.ac.uk/15727/

Stokes, Peter, Moore, Neil, Smith, Simon Martin, Larson, Mitchell Jonathan ORCID: 0000-0002-5506-0815 and Brindley, Clare (2017) Organizational Ambidexterity and the Emerging-to-Advanced Economy Nexus: Cases from Private Higher Education Operators in the United Kingdom. Thunderbird International Business Review, 59 (3). pp. 333-348. ISSN 10964762

It is advisable to refer to the publisher's version if you intend to cite from the work. http://dx.doi.org/10.1002/tie.21843

For more information about UCLan's research in this area go to http://www.uclan.ac.uk/researchgroups/ and search for <name of research Group>.

For information about Research generally at UCLan please go to http://www.uclan.ac.uk/research/

All outputs in CLoK are protected by Intellectual Property Rights law, including Copyright law. Copyright, IPR and Moral Rights for the works on this site are retained by the individual authors and/or other copyright owners. Terms and conditions for use of this material are defined in the policies page. 


\title{
Organizational Ambidexterity and the Emerging-to-Advanced
}

\section{Economy Nexus: Cases from Private Higher Education Operators in}

\section{the UK}

\author{
Professor Peter Stokes \\ Leicester Castle Business School \\ De Montfort University \\ The Gateway \\ Leicester \\ LE1 9BH \\ United Kingdom \\ Tel: +44 (0)116 2551551 \\ peterstokesmail@gmail.com
}

Peter Stokes is Professor of Leadership and Professional Development at Leicester Castle Business School (LCBC - De Montfort University, Leicester, UK). Previously he worked at the University of Chester Business School (UK) where he successfully completed faculty-wide Deputy Dean (2012-2015), Acting Executive Dean (2012-2014) and Director of Research and Knowledge Transfer assignments. He has taught, researched, published and reviewed extensively across a range of areas in world-class journals including: International Journal of Human Resource Management; Human Resources Management; European Management Review; International Business Review; and, Entrepreneurship and Regional Development. He is Editor-in-Chief of the International Journal of Organizational Analysis and holds senior roles in a range of international academic associations including UK Ambassador for the Association Francophone de Gestion des Ressources Humaines (AGRH). He has applied his work through national and international knowledge transfer and consultancy projects across a range of business sectors.

\author{
Dr Neil Moore \\ Centre for Work Related Studies \\ Faculty of Business and Management \\ University of Chester \\ Queen's Park Campus \\ Chester $\mathrm{CH} 47 \mathrm{AD}$ \\ United Kingdom \\ Tel: +44 (0)1244 511822 \\ Email: n.moore@chester.ac.uk
}

Dr Neil Moore (PhD, MA, PgCert, BA (Hons)) is a Senior Lecturer in the Faculty of Business and Management at the University of Chester. He lectures, tutors and consults in a range of business and management areas, including international business, management development, contemporary management issues in small and medium sized enterprises and sport management. His interest in business, management and sport led to his doctoral research into business management practices in the English professional football industry. He has also researched and published in a range of other areas including talent management, organizational behaviour, event management and research methodology. $\mathrm{He}$ is currently a visiting lecturer and academic advisor in a number of HE institutions in the UK and overseas. He is also an Associate Editor of the International Journal of Organizational Analysis. 
Dr Simon M. Smith

University of Winchester

Winchester Business School

Sparkford Road

Winchester, Hampshire

SO22 4NR

United Kingdom

Tel: +44 (0)1962 841515

Email: simon.smith@winchester.ac.uk

Dr Simon M. Smith is Senior Lecturer in Leadership and Management at the University of Winchester. He has expertise and interests in Leadership and Management, Human Resource Management, Organizational Behaviour, Organizational Analysis and International Business. His current research interests encompass Organizational Ambidexterity, global talent management, resilience, emerging market economies, Investors in People and training and development. In addition, Simon is an Associate Editor for the International Journal of Organizational Analysis.

\author{
Dr. Mitchell J. Larson \\ School of Business \\ Greenbank Building \\ University of Central Lancashire \\ Preston \\ PR1 2HE \\ United Kingdom \\ Tel: +44 (0)1772 894685 \\ Email: mjlarson@uclan.ac.uk
}

Mitchell J. Larson earned his PhD from the University of Wisconsin-Madison. He has published in the areas of business and organizational history and the history of sport. His research looks at the intersections and negotiations that take place among and between social institutions such as private and state-owned businesses, the higher education sector, the state, and elite organized sport. By adopting a longitudinal and often comparative approach to his research, he seeks to contextualize research findings into the landscape of the existing and evolving social fabric. Dr. Larson is associate editor of the International Journal of Organizational Analysis and Essays in Economic and Business History; he reviews for several journals including Business History, Management and Organizational History, the European Management Journal, and the Journal of Organizational Behaviour.

\author{
Professor Clare Brindley \\ Nottingham Business School \\ Nottingham Trent University \\ Room 604 Newton \\ Burton Street \\ Nottingham NG1 4BU \\ United Kingdom
}

Tel. +44 (0)115848 2758

Email: clare.brindley@ntu.ac.uk

Clare Brindley is Professor of Marketing and Entrepreneurship at Nottingham Trent University. She is an elected Fellow of the Royal Society of Arts, a member of the Chartered Institute of Marketing and has served as a Trustee/Director of the Institute of Small Business and Entrepreneurship and Nottingham Women's Centre. Her research is multi-disciplinary and has two central themes the small business sector and supply chain risk. Clare has published over 50 papers and is also an editorial board member of several leading publications. Her work has been presented at international conferences including the British Academy of Management, Irish Academy of Management and the Academy of Marketing. 


\section{Organizational Ambidexterity and the Emerging-to-Advanced}

\section{Economy Nexus: Cases from Private Higher Education Operators in}

\section{the UK}

\section{Executive Summary}

The expansion of advanced market economy (AME) firms into emerging market economies (EME) is well-documented. In recent decades, EME companies have moved increasingly into AMEs, especially within the manufacturing sector, as well as other important AME sectors such as higher education (HE). However, the latter have received less attention. This study conducts an in-depth qualitative analysis of two EME HE organisations operating in the international HE sector in London. The argument applies a theoretical framework of organisational ambidexterity with which to examine the contexts and complexities in collaborations between EME-HE and AME-HE firms. These argument surfaces, inter alia: differing dynamics in relation to institutional frameworks and sense-making; myopic internationalisation; tensions regarding organisational reputation, place, partner, and product legitimisation; unfulfilled reverse innovation and 'explorative-pull' phenomena. Overall, the paper develops novel conceptual frameworks of practical relevance which inform EME-AME firm collaborative operations in AME settings.

Key Words: ambidexterity, higher education, collaboration, emerging markets, advanced markets 


\section{Introduction}

Conventional international expansion journeys suggest that, in the initial stages of growth, companies often establish operations in national domestic markets. Having established national operations, they tend to seek expansion in other national economies, whether advanced market economies (AME) or emergent market economies (EME) (U.S. Department of Commerce, 2014; Anwar, 2015; Nwankwo, 2012; Saldanha, 2014; Yang \& Meyer, 2015). The experience of AME companies entering EMEs is well-documented (Beamish \& Lupton, 2015; Holtbrügge \& Baron, 2013; Sartor \& Beamish, 2014). These ventures frequently necessitate forms of collaborative partnership and there are numerous instances of mixed success and high failure rates in relation to cultural integration (Ahammad, 2014; Liu \& Woywode, 2013; Weber, Tarba, \& Öberg, 2014). EME national markets for 'home-grown' EME-based corporates have also received attention (McAdam et al., 2013). Nevertheless, there is a growing interest in the experiences of companies originating from EMEs entering AMEs (Kedia, 2015). Extant literature has been valuable, but it has focused predominantly on certain sectors such as manufacturing and major capital infrastructure investment (Xia et al., 2014) meaning sectors such as the international higher education (HE) sector have been under-explored. This study addresses these lacunae by focusing on two private EME South-East Asian HE case companies (originating in Indonesia and Vietnam) and their move into a substantial AME market (London) through partnership with an AME-HE institution. It develops both theoretical and practical insights into EME-firm collaborative dynamics within AME markets.

The United Kingdom (UK), and especially London, is an important HE destination market. Global data indicate that there are 178 million individuals currently in HE many attending 
private institutions rather than government funded courses (Department of Business, Innovation and Skills (UK), 2013:6) with a HE sector estimated to be valued at $£ 73$ billion (Universities UK, 2014). Therefore, HE represents a significant aspect of the evolving knowledge economy and is often regarded as a key area of national competitive advantage for AMEs. A market of this size provides extensive business expansion opportunities for private enterprise HE institutions (HEIs). Consequently, despite reluctance from some AME-HEIs to engage in 'entrepreneurial' imperatives and grow overseas activities, many universities in AME settings, emulating their AME corporate counterparts, have collaborated with EME firms and institutions - particularly in South-East Asia and the Middle-East (Alajoutsijäryi, Juusola \& Lamberg, 2014; Philpott, 2011). Although the globalisation of HE has been well-documented (Ennew \& Greenway, 2012; Guillotin \& Mangematin, 2015), there have been relatively few examinations of EME-HEIs and their attempts to develop operations in AMEs. In the instances where this has occurred, a common mode for EME firms has been to establish a partnership with an established AME-HEI. However, collaboration between quasi-public AME-HEIs and private EME-HEI providers represents a fusion of distinctive organisational cultures intertwined with complex background national cultural contexts.

The AME-HEI and EME-HEI interface presents a particular dynamic which the paper explores through a framework of the exploitative and explorative stances of organisational ambidexterity (Birkinshaw \& Gibson, 2004; Birkinshaw \& Gupta, 2013; Stokes et al., 2015). Exploitative ambidextrous postures see organisations having a propensity to operate within clearly delineated organisational boundaries, focusing on extant resources, undertaking limited innovation and generally adopting risk-averse behaviors (O’Reilly \& Tushman, 2008, 2011; Raisch \& 
Birkinshaw, 2008; Simsek, 2009). In contrast, in explorative behaviour the organisation traverses its limitations and markets, identifies novel resources and adopts innovative and risk-espousing postures (O'Reilly \& Tushman, 2004, 2008, 2011, 2013). In HE contexts, organisational ambidexterity poses theoretical and practical issues worthy of attention and this study explores these through the following research question:

RQ. How do ambidextrous exploitative-explorative dynamics operate in AME-HEI and EME-HEI collaborations?

We commence by examining ambidexterity in relation to EME and AME contexts. Subsequently, key factors which shape HE collaborative relationships leading to theoretical implications and practical insights are identified and a conceptual model developed. The findings, discussion, and recommendations are contextualized within the organisational ambidexterity framework offering insights for HE collaborations.

\section{Literature Review}

\section{EME-HEI and AME-HEI collaborations - ambidextrous tensions and dynamics}

A recurrent feature of globalisation concerns the entry of AME corporations into EME contexts (Buckley, Elia \& Kafouros, 2014; Khanna, Palepu \& Bullock, 2010). Nevertheless, EME firms establishing operations in AMEs have become increasingly common (Azmat \& Ha, 2013; Kedia, 2015; Teagarden, 2013). In the global context, a number of well-known examples of EME firms entering AMEs exist including major conglomerates such as Tata (India), Embraer (Brazil) and Koc Holdings (Turkey) (Economist, 2011). These developments have involved certain sectors, in 
particular, manufacturing, industrial goods and capital infrastructure investment (Jayaram \& Avittathur, 2015). Organisational ambidexterity postulates that companies moving into new markets may confront differing forms of environmental dynamic context with 'exploitative' and 'explorative' conditions (Birkinshaw \& Gupta, 2013; Meglio, King \& Risberg, 2015; Stokes et. al., 2015; Junni et al., 2015; Xing et al., 2016). Exploitative ambidextrous organisational conditions and behaviors display propensities to identify and maintain clear boundaries, existing knowledge bases, resources and markets. Thus, exploitative stances tend to favor conservatism and risk-aversion. Alternatively, explorative ambidextrous responses involve organisations embracing new domains, novel boundaries of operation and innovation of new products and knowledge, and, emerging markets involving radical risk-taking approaches (Junni et al., 2013; O'Reilly \& Tushman, 2011; Raisch, Birkinshaw, Probst \& Tushman, 2009; Simsek, 2009). In addition to organisational dispositions, it is also possible to discern characteristic ambidextrous national environmental traits (using Hansen \& Wethal, 2014; Welfens, 2013). AME environments generally exhibit more innately embedded exploitative states but are not necessarily devoid of explorative conditions. In contrast, EME contexts often exhibit strong explorative characteristics (Kirkpatrick, Lee \& Nixson, 2010; Chakrabarty \& Bass, 2013; Li, Kumar \& Von Glinow, 2015). It is evident that the challenges of marrying differing organisational and national contexts can be difficult as evidenced by very poor collaborative success rates (Ahammad, 2014; Liu \& Almor, 2014; Liu \& Woywode, 2013; Xing, 2014).

A very extensive literature maps the pedagogic issues surrounding globalisation of education and the movement of international students between various global regions (Lumby \& Foskett, 2015; Marginson \& Wende, 2007; Morley, Marginson, \& Blackmore, 2014), but there is less written 
on $\mathrm{HE}$ as a business sector encompassing the transfer of capital, revenues, innovation and knowledge between markets. Within this focus, the market entry of EME-HE firms and institutions into AME environments receives less attention. An important vehicle for the expansion of EME-HEIs has been the private sector (as opposed to the public, state-funded institutions). Furthermore, the UK HE competitive environment has experienced substantial change in recent decades (Shiel, 2008; Walker, 2015). Therein, international student applications play a major role in ensuring revenue streams, especially for postgraduate programs (Walker, 2015). Therefore, HEIs represent significant sites of regional and national competitive advantage (Porter, 2008; Slaughter \& Cantwell, 2012). International activity is driven by a number of factors including inter alia: income generation from elevated international students' fees, as well as, enriching the experience of students and staff through cross-border educational experiences (Walker, 2015). As internationalization expands, the key issues of maintaining and enhancing program quality and institutional reputation become vitally important.

Collaboration between EME-HE firms and AME-HE organisations raises a range of contrasting cross-cultural, social, economic, institutional and ambidextrous tensions. Institutions located in AME-HE market contexts tend to exhibit a series of well-established, relatively inflexible (or slow to adapt), clearly delineated boundaries based on long-standing knowledge bases which resonate with exploitative dimensions of organisational ambidexterity. In contrast, EME-HE contexts tend to exhibit highly adaptable explorative dimensions and an ability to re-invent and innovate due to the absence of extensive reputational and traditional legacies. The contrasting respective normative exploitative and explorative states of AME-HEIs and EME-HEIs are deeply embedded, induced by a set of underlying cultural factors which have the potential to 
impact upon EME-HEI and AME-HEI collaborations. These factors revolve around, for example: institutional frameworks (possibly linked to contextual issues such as institutional voids - i.e. weak or absent national institutional fabric and frameworks (Anheier, 2014; Liu, 2011)); variances in organisational mobility and agility; consequent effects of reverse innovation and knowledge transfer cycles; and, questions of acquired legitimacy. Consideration of these factors provides an opportunity for a more 'fine grained' examination of exploitative and explorative behaviors which, in turn, will inform both theory and practice pertaining to how AME-HEI and EME-HEI collaborations operate against an ambidextrous backdrop.

As noted above, strong ambidextrous contrasts occur in AME and EME environments and are likely to be reflected in AME-HEI and EME-HEI organisational operations. In order to explore these states, the argument now introduces what are henceforth termed intermediate ambidextrous states and behaviors operating at the interface of EME and AME firms and contexts. These can be further expanded through the terms intra-exploitative and inter-exploitative dispositions and, commensurately, intra-explorative and inter-explorative dispositions. The intra-prefix points at exploitative or explorative actions focused internally and aimed towards a given organisation's own operations, whilst the prefix inter- highlights actions oriented to environments and institutional frameworks external to the organisation. This important distinction affords a more granular analysis of the operation of ambidexterity in HE organizational settings. The ambidextrous postures and behaviors of various HEIs also need to be understood in relation to the contexts of given institutional frameworks. Institutional frameworks point (though not exclusively) at the network of government and forms of organisation and governance which combine to create the political, social, cultural and economic fabric of a country in which 
organisations operate (DiMaggio \& Powell, 1983; Lawrence, Suddaby \& Leca, 2011; Suddaby, Foster \& Mills, 2014). The above literature review and theoretical development permit the conceptual development of a composite model for modes of ambidexterity in relation to EME/AME HE organisations and their macro-environments. This is detailed in Table 1 below:

\begin{tabular}{|c|c|c|c|c|}
\hline \multicolumn{5}{|c|}{$\begin{array}{l}\text { Table 1: A Model of Ambidextrous Dispositions and Modes } \\
\text { in AME-HE \& EME-HE Collaborations }\end{array}$} \\
\hline & \multicolumn{2}{|c|}{$\begin{array}{l}\text { Prevailing Exploitative Environment } \\
\text { (i.e. Typical AME environment) }\end{array}$} & \multicolumn{2}{|c|}{$\begin{array}{l}\text { Prevailing Explorative Environment } \\
\text { (i.e. Typical EME environment) }\end{array}$} \\
\hline & $\begin{array}{c}\text { Intra-exploitative } \\
\text { disposition (i.e. } \\
\text { actions oriented } \\
\text { within own } \\
\text { organisation) } \\
\end{array}$ & $\begin{array}{c}\text { Inter-exploitative } \\
\text { disposition (i.e. } \\
\text { actions oriented } \\
\text { between AME \& } \\
\text { EME organisations) }\end{array}$ & $\begin{array}{c}\text { Intra-explorative } \\
\text { disposition (i.e. } \\
\text { actions oriented } \\
\text { within own } \\
\text { organisation) } \\
\end{array}$ & $\begin{array}{c}\text { Inter-explorative } \\
\text { disposition (i.e. } \\
\text { actions oriented } \\
\text { between AME \& } \\
\text { EME organisations) }\end{array}$ \\
\hline \multirow[t]{3}{*}{ EME-HEI } & $\begin{array}{l}\text { High Conservative/ } \\
\text { Traditionalist Mode } \\
\text {-Organisational } \\
\text { actions make } \\
\text { culturally-bound } \\
\text { hierarchies and } \\
\text { procedures of } \\
\text { paramount } \\
\text { importance. } \\
\text {-Maintenance of the } \\
\text { status quo and high } \\
\text { value placed upon } \\
\text { past successes and } \\
\text { experiences. }\end{array}$ & $\begin{array}{l}\text { Measured- } \\
\text { Collaborative Mode } \\
\text {-Organisation } \\
\text { undertakes very } \\
\text { limited, extensively } \\
\text { assessed and } \\
\text { negotiated } \\
\text { collaborations. } \\
\text {-Likely to be closely } \\
\text { monitored by a } \\
\text { conservative and } \\
\text { cautious institutional } \\
\text { framework. } \\
\text {-Decision making is } \\
\text { bureaucratic to } \\
\text { protect existing } \\
\text { position. }\end{array}$ & $\begin{array}{l}\text { Constant } \\
\text { Reconfiguration } \\
\text { Mode } \\
\text {-Organisation in } \\
\text { constant state of self- } \\
\text { reinvention as it } \\
\text { reconfigures } \\
\text { resources to meet } \\
\text { environmental } \\
\text { opportunities and } \\
\text { challenges. } \\
\text {-Likely to try to } \\
\text { build defensive } \\
\text { boundaries against } \\
\text { the explorative } \\
\text { surroundings. } \\
\text {-Teams are } \\
\text { (re)formed to } \\
\text { undertake specific } \\
\text { projects - loose } \\
\text { configurations of } \\
\text { staff. }\end{array}$ & $\begin{array}{l}\text { Commercial and } \\
\text { Radical Mode. } \\
\text {-Organisation is a } \\
\text { vehicle for income } \\
\text { and profit generation } \\
\text { capable of shifting } \\
\text { resources at short } \\
\text { notice to alternative } \\
\text { projects. } \\
\text {-Little sincere } \\
\text { engagement in } \\
\text { pedagogic mission of } \\
\text { its projects. } \\
\text {-Focus is upon } \\
\text { maximising returns } \\
\text { through } \\
\text { opportunism. }\end{array}$ \\
\hline & $\begin{array}{l}\text { High risk aversion } \\
\text { and likely to operate } \\
\text { within a highly } \\
\text { regulated } \\
\text { environment. }\end{array}$ & $\begin{array}{l}\text { Measured attitude to } \\
\text { risk. }\end{array}$ & $\begin{array}{l}\text { Open pre-disposition } \\
\text { to risk. }\end{array}$ & $\begin{array}{l}\text { Propensity towards } \\
\text { risk and potent } \\
\text { agility and } \\
\text { adaptability. }\end{array}$ \\
\hline & (e.g. Reasonably & & & (e.g. Private EME- \\
\hline
\end{tabular}




\begin{tabular}{|c|c|c|c|c|}
\hline & $\begin{array}{l}\text { well-established state } \\
\text { EME-HEI operating } \\
\text { in a highly regulated } \\
\text { HE institutional } \\
\text { environment such as } \\
\text { Singaporean HE } \\
\text { model.) }\end{array}$ & $\begin{array}{l}\text { modern EME-HEI } \\
\text { keen for } \\
\text { collaboration with } \\
\text { AME but very } \\
\text { mindful of being } \\
\text { monitored by } \\
\text { institutional } \\
\text { agencies.) }\end{array}$ & $\begin{array}{l}\text { modern state or } \\
\text { private EME-HEI.) }\end{array}$ & HEI) \\
\hline \multirow[t]{3}{*}{ AME-HEI } & $\begin{array}{l}\text { High-Conservative } \\
\text { (Committee and } \\
\text { Bureaucrat) Mode: } \\
\text { Organisational } \\
\text { actions focus } \\
\text { intensively on } \\
\text { internal procedures } \\
\text { in response to a } \\
\text { conservative and } \\
\text { stable institutional } \\
\text { external } \\
\text { environment. }\end{array}$ & $\begin{array}{l}\text { Elitist-Network } \\
\text { (Limited Exchange }) \\
\text { Mode } \\
\text { Organisation tends to } \\
\text { transact between } \\
\text { only AME-HEIs of } \\
\text { its own perceived } \\
\text { equivalent standing - } \\
\text { state/public-funded } \\
\text { research intensive } \\
\text { EME-HEIs. }\end{array}$ & $\begin{array}{l}\text { Enlightened-Liberal } \\
\text { Mode }\end{array}$ & $\begin{array}{l}\text { Entrepreneurial- } \\
\text { Marketised Mode } \\
\text { Organisation } \\
\text { considers } \\
\text { collaboration as a } \\
\text { commercial } \\
\text { enterprise and } \\
\text { response to HE } \\
\text { marketization and } \\
\text { commercialisation. } \\
\text { (May well be } \\
\text { evidence of deep } \\
\text { institutional void in } \\
\text { the macro-economic } \\
\text { setting) }\end{array}$ \\
\hline & $\begin{array}{l}\text { Dominated by long- } \\
\text { established protocols } \\
\text { and metrics that are } \\
\text { inflexible and may } \\
\text { not fit with changes } \\
\text { in the external } \\
\text { environment. }\end{array}$ & $\begin{array}{l}\text { Prevailing attitude is } \\
\text { one of maintaining } \\
\text { control and engaging } \\
\text { with partners who } \\
\text { will enhance } \\
\text { reputation and } \\
\text { standing. }\end{array}$ & $\begin{array}{l}\text { HEI aims to limit } \\
\text { risk and exposure but } \\
\text { recognizes the value } \\
\text { of engagement and } \\
\text { the potential for } \\
\text { organisational } \\
\text { development and } \\
\text { learning. }\end{array}$ & $\begin{array}{l}\text { HEI aims to respond } \\
\text { quickly and flexibly } \\
\text { to opportunities and } \\
\text { will embrace risk if a } \\
\text { strong case for } \\
\text { partnership is } \\
\text { evidenced. }\end{array}$ \\
\hline & $\begin{array}{l}\text { High risk aversion } \\
\text { /ultra- conservatism } \\
\text { (e.g. Historic } \\
\text { research-intensive } \\
\text { HEI with strong } \\
\text { financial resources. } \\
\text { Not prone to seeking } \\
\text { reverse innovation } \\
\text { possibilities as it is } \\
\text { content with its own } \\
\text { knowledge bases and } \\
\text { traditions.) }\end{array}$ & $\begin{array}{l}\text {-Risk averse. } \\
\text {-Measured and } \\
\text { cautious innovation } \\
\text { within safe and } \\
\text { established } \\
\text { institutional } \\
\text { frameworks. } \\
\text { (e.g. Historic or } \\
\text { Modern AME-HEI } \\
\text { but with strictly } \\
\text { limited policy of } \\
\text { number of } \\
\text { international } \\
\text { partners.) }\end{array}$ & $\begin{array}{l}\text { (e.g. Modern and } \\
\text { recently founded } \\
\text { AME-HEI with need } \\
\text { to explore and } \\
\text { extend income } \\
\text { streams.) }\end{array}$ & $\begin{array}{l}\text { Appetite for quality; } \\
\text { financial and } \\
\text { reputational risk is } \\
\text { relatively high } \\
\text { compared to inter- } \\
\text { explorative } \\
\text { disposition. } \\
\text { (e.g. Modern and/or } \\
\text { private AME-HEI in } \\
\text { a mode of constant } \\
\text { agile and radical } \\
\text { transformation. } \\
\text { Constantly seeking } \\
\text { reverse innovation } \\
\text { opportunities.) }\end{array}$ \\
\hline
\end{tabular}


Table 1 synthesises and models the various elements and theoretical dispositions in ambidextrous AME-HE and EME-HE collaborations and operations. It develops an applied theoretical framework encompassing a range of modes through which to examine cases from these environments. The next stage of the discussion outlines a methodological approach to examine theses ambidextrous modes in empirical context.

\section{Methodological approach}

This paper focuses on an examination of the processes that underpin ambidextrous drivers and contextual factors operating in relation to EME-HEIs entering AME environments and considers two EME-HEI case studies involving a South-East Asian EME-HEI and an AME-HEI UK (London) connection (see Table 2). Anteby, Lifshitz and Tushman (2014:3) indicate that: 'By asking 'how' questions, qualitative data get at underlying mechanisms'. For this reason, the present argument adopts a 'how' question, within a qualitative framework, which will allow it to surface extensive and rich data so as to better elaborate under-explored phenomena (Edmondson and McManus, 2007). The research employs a case study approach (Eisenhardt \& Graebner, 2007; Siggelkow, 2007; Stake, 2008; Yin, 2009) and adopts a qualitative research structure (Mordi, Mmeih \& Ojo, 2013) to develop detailed data. An inductive approach enables the development of emergent theory 'by recognizing patterns of relationships among constructs within and across cases and their underlying logical arguments' (Eisenhardt \& Graebner, 2007: 25). In addition, the development and use of comparative cases offers the opportunity to develop a 'rich picture' and explore the phenomena within, rather than independent of, their 'real-world' contexts (Gibbert, Ruigrok \& Wicki, 2008). 
The two cases focus on HEIs originating from Indonesian and Vietnamese EMEs collaborating with a British HEI partner in the UK. The sampling was based on a convenience sample as access is always a significant challenge in this sphere due to inherent commercial sensitivities. The study collected data from 21 face-to-face semi-structured interviews with academic staff (Bogdan \& Biklen, 2007) (see Table 3 below). The staff were selected using a stratified sampling frame which sought to reflect the tiers of the organizational structure. In the various case settings 18 staff in EME-HEI-1, 15 staff in EME-HEI-2 and 10 staff in AME-HEI were approached by telephone and face-to-face to participate resulting in respectively 8,9 and 4 participants agreeing to do so. The low response rate in the AME-HEI may be attributable to a general disaffection with the collaboration by the time the study was conducted. Semi-structured interviews enable respondents to 'tell their own story', enabling the interviewer to gain a more comprehensive understanding of the participants' 'world' (Polonsky \& Waller, 2005; Theodorakopoulos \& Figueira, 2012). The interviews lasted between thirty and ninety minutes. Confidentiality and anonymity were guaranteed. These were recorded and transcribed. The research followed normative protocols for interviews in relation to validity and reliability. Only a small number of prepared questions were used to encourage participants to provide rich pictures by responding flexibly. Polonsky and Waller (2005: 106) advise this form of flexibility because 'The method chosen should match the degree of flexibility you require in terms of informational needs ... [and that in]...exploratory research, you may need a method that provides room for respondents to give answers that the researcher may not have anticipated.' 
The data were analysed through template analysis. This approach is appropriate for the signalling of emergent themes from complex organisational cultural settings and interactions (King \& Horrocks, 2010). Template analysis is conducted by carrying out repeated readings of the data by two team members in order to reinforce reliability. The preliminary template analysis process created a priori codes and this was followed by subsequent re-readings (employing the a priori codes) in order to establish 'segments' aligned to codes. In the initial stage of coding, the research team coded independently later coming together to compare and confer. Where segments of data could not be readily aligned, these generated additional a priori codes. By undertaking readings of a number of transcripts, it was possible to establish the overall code range in line with practice outlined by McDowall \& Saunders (2010) in relation to which the data could be categorised. Here, the aim is to generate insights that go beyond mere description by raising awareness of aspects that may inform the future strategy of others operating within the field. Importantly, following qualitative approached in general, our cases are not representative, nor our findings extensively generalizable; rather, our work develops insights into emergent themes in the field (Eisenhardt \& Graebner, 2007; Siggelkow, 2007).

\section{The case study context: London (UK) - a hub for EME-HE firms entering AMEs}

In $2015,425,625$ overseas students were studying in the UK according to the UK Council for International Student Affairs (UKCISA) and this accounted for approximately 13\% of the global market share of international mobile higher education students (UKCISA, 2015). In terms of London's share of the global HE market, the UK capital hosted 102,965 international students placing it as the premier student overseas study destination, beating New York and Sydney. The UKCISA report signalled that of the $191 \mathrm{HE}$ providers based in London 148 of them were 
privately funded institutions (i.e. non-government funded) (http://www.londonhigher.ac.uk, 2015). In the exploitatively AME-structured UK market these HEIs operate in modes common to that domain (see Table 1). The intensity of the London context is underlined by the fact that international students from over 200 countries engage with 30,000 programs of study (Study London, 2015). These observations emphasise that, along with maintaining its wider global appeal, London has become the leading destination for international HE students and this has facilitated a proliferation of privately-funded HE institutions aiming to attract students in this highly lucrative market. Many EME-HEIs are obliged to form partnerships with British institutions which possess degree awarding powers from central government. In addition, UK government agencies monitor the financial health of institutions and the Quality Assurance Agency (QAA) oversees quality standards in the sector (HEFCE, 2015). Crucially, for each recruited non-European Union international student, HEIs (both EME and AME) must acquire a Certificate of Acceptance (CAS) from the UK government. The CAS provides a unique number to each student. These allocations are limited in number and are closely monitored by HEIs. The UK Visas and Immigration office (UKVI) obliges institutions to monitor student attendance and if an HEI does not maintain strict records of student attendance, or the student does not comply with attendance requirements, then the CAS may be withdrawn and the student deported. Where an HEI causes UKVI serious concerns about its ability to manage international students, CAS granting rights may be withdrawn altogether, meaning that the HEI can no longer recruit overseas students. Such consequences are very damaging both reputationally and financially for an institution. 
Thus, the UK has a highly developed, longstanding, strongly regulated, sophisticated and wellreputed AME system of HE provision (OECD, 2015). This parallels certain EME-HE contexts which, while residing in national market settings which are broadly explorative in nature, nevertheless establish their own quality systems which have stable, exploitative dimensions and can produce High-Conservative-Traditional and Measured-Collaborative modes of operation. (e.g. the Singaporean and Malaysian HE quality bodies (Lo, 2014; Mok, 2011)). Furthermore, over recent decades, various UK governments have undertaken extensive privatisation of many areas of the public sector. This has cultivated a mind-set which, while not always necessarily accepting such changes, remains open to the potential role of higher risk private capital and market-led responses in traditional public sector arenas. Nevertheless, AME-HEIs (particularly those associated with the state/public sector), having built up solid reputations over long periods, are naturally mindful of reputational risk. This is particularly prevalent in the exploitative HighConservative and Elitist-Network modes (Table 1). Conservation of 'brand' is imperative for any self-respecting HEI reputational protection strategy (Wolfe \& Chasser, 2012). EME partners may bring more explorative and flexible approaches to the conduct of activities (displaying for example Constant Reconfiguration or Commercial and Radical modes). In this way, many EME firms often exhibit differing sensemaking (Weick, 2009) to AME firms.

\section{The Case Studies}

The first case organisation, EME-HEI-1 (a summary of key information relating to each of the case study organisations is provided in Table 2), originated in Indonesia and built a substantial business in its home nation and neighboring countries before developing a London base from 
which it connected and engaged with a range of UK-based HEIs. EME-HEI-1 is highly successful with strong international student recruitment and close relationships with a range of UK and other international university institutions. It occupies prestigious premises in central London. EME-HEI-1 prima facie might be considered to be operating broadly in, following the nomenclature developed in Table 1, a varying combination of Measured-Collaborative and Constant Reconfiguration mode. In terms of CAS and attendance monitoring for UKVI purposes, the organisation employed state-of-the-art technology desired by the UK AME-HEI partner. Indeed EME-HEI-1 offered to advise the UK HEI about the possibility of implementing a similar system. The British institution sought knowledge of, and access to, new recruiting and monitoring approaches in a clear instance of potential (EME to AME) reverse innovation (Govindarajan \& Trimble, 2013).

The second case organisation, EME-HEI-2, originated from Vietnam and rapidly built operations in London although for various reasons this met with limited success. EME-HEI-2 experienced a range of difficulties securing the necessary licences from UK authorities. This, in turn, created cash-flow problems stemming from the reduced ability to recruit students. The premises purchased in London by EME-HEI-2 were a Victorian-aged building (dated pre-1900) though architecturally valuable, had become rather dilapidated. This created an unfavorable impression around the institution. EME-HEI-2 could be deemed, following Table 1's classification, to be operating across the Constant-Reconfiguration and Commercial and Radical modes.

\section{Results}


The results provide an insight into the template analysis a priori features surfaced in the data. A broad overview of the coding is provided in Table 4 at the rear of the paper and the results section is laid out in the same format as the Table.

\section{Attitudes to Regulatory Frameworks (Ambidextrous Exploitative-Explorative Tensions)}

Queries arose over EME-HEI-1's compliance with UK quality procedures. EME-HEI-1 demonstrated awareness of UK or international quality systems but did not follow them closely. The AME-HEI and EME-HEI-1 teams, at the outset of the relationships, talked about quality procedures for programs and products but could not mutually deliver on these assurances. Moreover, EME-HEI staff seemed to show only moderate concern about it. EME senior management and staff exhibited a mind-set that anything could be rectified post-hoc which was simply not feasible within the ambidextrously exploitative rigors of the QAA framework.

\footnotetext{
'Yes, certainly, we have been on a learning curve together working through the [quality] assurance arrangements but we are sure we will get there. There is always a way forward in these things.' [Academic Quality Director - EME-HEI-1]
}

In this manner, EME-HEI-1 demonstrated an explorative attitude to the AME-HEI institutional protocol requirements:

\footnotetext{
'Just when we get the last request or change [by EME-HEI-1] agreed and arranged we get another one - often that modifies or even throws the last one out of the window. It can be tiring and exasperating.' [Liaison Director - AME-EHE]
} 
Within the EME-HEI-2 case study, the tensions with UK authorities created challenges of securing all the operational and regulatory compliance documents. In turn, this interrupted international student recruitment which had subsequent impacts on revenues for both partners. However, the owner and director of EME-HEI-2 took several actions which clearly indicated that such obstacles could be addressed perhaps by taking regulatory actions in the Vietnam base:

'We plan to run the operation through the Vietnam operation which will facilitate compliance with any regulatory requirements.' [Owner-Director of EME-HEI-2]

'We are still monitoring progress in relation to fitting in with the UK quality processes. There seems to be an idea [in EME-HEI-2] that there may be a way around these but there simply is not and we must have things done properly.' [Business Manager AMEHEI]

These two statements clearly display competing ambidextrous explorative and exploitative mindsets regarding how regulatory frameworks might be addressed. Overall, within EME-HEI-2 there seemed to be a flexible (indeed ambidextrous explorative) attitude to adhering to protocols and regulatory schemes. This ambiguous stance created great delay in building the relationship with the more exploitative AME-HEI. Thus, the issue of the role of protocols and regulatory frameworks emerged as an interesting feature to consider within the overall differing ambidexterity of the various partner postures and contexts. 


\section{Organisational Reputation and Legitimisation}

The major risk for the British-based institution quickly emerged as reputational in terms of assuring the quality of delivery by an EME provider. This proved an increasingly important issue for AME-HEI as the relationship continued and quality and procedural failings persisted. The management of, and liaison with, EME staff also proved difficult.

'This is potentially high-risk activity for us and we need to be very careful. Sometimes, I think the senior management are blinded by the promise of revenues and they just don't seem to see the issues that could undermine the whole operation and our credibility. If things go wrong in this collaboration, EME-HEI-1 will just go and find another partner. We could be left picking up the pieces of our reputation.' [Lead Academic - AME-HEI]

Nevertheless, the divergent views surrounding the legal arrangements and protocols, as well as issues of sourcing and infrastructure at its London operation center, meant that the revenue streams for either collaborating partner never commenced. Equally, the AME-HEI demonstrated increasing concerns over the explorative lack of adherence by EME-HEI-2 to quality issues. It can be stated that this tension over competing expectations over notions of legitimacy connected to place, product and partners represented a further overall dimension of ambidextrous tensions in a AME-HEI and EME-HEI relationship.

\section{Unfulfilled Promises and Expectations (Absence of an Ambidextrous Equilibrium)}

In relation to EME-HEI-1, a further sign of ambidextrous tensions and difficulties in the relationship with the AME-HEI resulted from disappointment regarding the lack of reverse 
innovation. The AME-HEI entered the agreement encouraged by promises regarding the sharing of state-of-the-art student attendance monitoring technology. This enabled EME-HEI-1 to comply with the rigorous obligations to monitor international students for compliance purposes with regards to UKVI restrictions. This reverse innovation (i.e. technology transfer from EMEHEI-1 to AME-HEI) never occurred and seemed to be 'conveniently forgotten' by EME-HEI-1. Equally, EME-HEI-1 stated that it would facilitate AME-HEI's entry into several EME student markets. While tentative discussions occurred regarding this - and AME-HEI staff were at one moment on the point on organising exploratory visits accompanied by EME-HEI-1 staff - again the initiative stalled and failed. Therefore, EME-HEI-2 never presented any real prospect of reverse innovation for AME-HEI. Rather, all the knowledge and reputational capital came from the AME-HEI. In this regard, the relationship proved to be a rather expedient one for EME-HEI2, and it later transpired that it had recently exited a relationship with another AME-HEI due to similar issues. This new relationship augured, for EME-HEI-2, an opportunity to re-construct some credibility with the AME-HEI. The AME institution hoped this would improve recruitment to its modest network in EMEs. Thus, it might be proposed that an explorative effect of the EME-HEI's posture was the relaxed and shifting view it took on prior discussions and agreements.

\section{Mismatching Resources (in Respect of Ambidextrous Fluctuations)}

As indicated above, a number of the emergent difficulties arose due to persistent underresourcing by EME-HEI-1 of the UK teaching team. While the AME-HEI did earn revenue from the collaboration, there were nevertheless hidden staffing and opportunity costs of AME-HEI staff-time spent monitoring and reacting to the changing requests of EME-HEI-1. This, 
combined with non-delivery into AME-HEI courses of promised student numbers, eroded the anticipated revenue stream for AME-HEI and represented something of a hidden cost to stretching into explorative postures. The over-extension of existing staffing bases in the AMEHEI can be seen to be a challenge to the exploitative posture of senior management who believed that internationalisation could be managed through extant organisational structures and resources.

\section{Explorative Pull}

The AME-HEI displayed a generally clear conservative behaviour pattern in relation to risk taking. However, with the supposed promise of access to international networks, reverse innovation of student monitoring technologies, and hoped for resultant income streams, the AME-HEI senior management pushed strongly towards collaboration with the EME-HEIs.

'The Senior Management have discussed projected [income figure X] and they are eager to see it realised.' [Business Manager - AME-HEI in briefing to AME-HEI staff]

This push seemed to occur largely on the basis of verbal guarantees and discussions rather than contractual stipulations largely as a result of the personal relationships which had developed between the highest level managers in the respective organisations. This led the AME-HEI into unfamiliar risk territory and ambidextrously explorative-style behaviour. As such, this behaviour developed a form of dangerous 'explorative pull' for the AME-HEI towards the EME context. This clearly contained a number of risks in relation to related issues (i.e. unfulfilled promises, reputation etc.), but it is important to note the strength of the 'pull' and its forces. 


\section{AME Management Imperatives}

Although operating with essentially a small-to-medium-sized enterprise (SME)-style management structure, EME-HEI-1 was nevertheless a well-rehearsed and well-presented operation functioning on an international basis with platforms in several EMEs. The organisation franchised a range of the AME-HEI partner programs and offered UK-branded courses to its extensive international EME student market. In this manner EME-HEI-1 displayed interexplorative dispositional behavior through the collaboration in the UK market and equally was able to undertake considerable intra-explorative behavior in reshaping its operations to marry with the AME-HEI prerequisites. Initially the British partner was willing to help the sale of its programs through the EME-HEI-1, however, over the course of the year a series of challenges emerged. Staff at the AME-HEI were instructed to support EME-HEI-1 to make the partnership successful. This was challenging as AME-HEI employees knew that senior management were pressuring people to make the partnership successful without committing the necessary time and resources to ensure success:

'We seem to have to do everything for them and if we don't then we get jumped on by [AME-HEI] senior management.' [Lead Academic - AME-HEI]

As such, this seemed to display a clear exhortation by senior AME-HEI management for staff to move towards more explorative styles of behaviour and this raised attendant issues. Any AMEHEI employee who appeared to question or resist the EME-HEI initiative risked being ostracised by senior management and this pushed many people into reluctant compliance. 


\section{Ethnocentric Goal Myopia}

The potential benefits accruing to the AME-HEI from collaborating with the EME firms included opportunities to engage in overseas $R \& D$, develop an understanding of marketing in emerging countries and the establishment of networks of commercially valuable contacts (Buckley, Elia \& Kafouros, 2014). For the AME institution, the benefits of aligning itself with the explorative environments of the EME-HEI-1 and EME-HEI-2 institutions were primarily related to the possibility of achieving rapid growth in international student numbers. The relationship with the EME-HEIs offered access to international networks without, it was envisaged, undergoing the full experiential curve of forming agency partnerships and undertaking extensive marketing. The AME-HEI sought enhanced reputational benefits through the prestige of having an enlarged international profile (Buckley \& Hashai, 2014; Buckley, Elia \& Kafouros, 2014). It might be suggested, in fact, that both the AME-HEI and the EME-HEI partners suffered from a form of ethnocentric goal myopia - a gaze preoccupied with one's own goal which occludes the full consequences of the goal of the other. In summary, the coded data of the findings provides insight a range of features which characterise the ambidextrous landscape of the AME-HEI and EME-HEI collaboration.

\section{Discussion}

This paper presents evidence of the collaborative challenges faced between two organisations from different cultures within the context of HE (Ahammad, 2014; Liu \& Woywode, 2013; Weber, Tarba, \& Öberg, 2014). Building on previous literature (e.g. Birkinshaw \& Gibson, 2004; Birkinshaw \& Gupta, 2013; Stokes et al., 2015), these differences are further elaborated by 
employing the lens of the exploitative and explorative dimensions of ambidexterity. From the data, the AME-HEI clearly struggled within its inherently exploitative institutional framework to adapt to the explorative approaches of the EME-HEIs, and this contributed towards many of the tensions highlighted in the results. Consequently, the AME-HEI found itself drawn away from its traditional High Conservative intra-exploitative mode (within its overall exploitative macroenvironment) towards an inter-explorative mode in a surrogate explorative environment created by imported EME-HEI values. This effect was identified and termed 'explorative-pull', whereby the AME-HEI (which as indicated above, in many ways, displayed a High-Conservative/Elitist Network mode mentality among senior management) was nevertheless drawn inextricably towards more explorative positions such as the Entrepreneurial-Marketised mode. The AMEHEI grew increasingly uncomfortable in this ambidextrously explorative situation.

The application of the organisational ambidexterity framework clearly highlights potential struggles within HEI collaborations where the mind-sets and home contexts are tangibly distinctive. The public sector AME, while promoting more entrepreneurial activity towards internationalisation, nevertheless remained within its organisational framework and wrongly expected that the private EME-HEIs (with their inherent propensity for explorative flexibility) would comply. There was a misplaced assumption by the AME-HEI that the EME-HEIs would moderate their explorative propensities (and thus potentially reduce organisational flexibility and competitiveness) in exchange for AME institutional stability, legitimacy, and knowledge. However, this assumption underestimated the EME-HEI ambition to remain flexible and make profits. Thus, a fundamental lack of understanding led to differing expectations and complications in the relationship. 
From the literature and empirical results, a range of factors concerning the EME firms' entry into the London AME environment raised consequent issues. With regards to institutional regulatory and quality frameworks, neither EME-HEI-1 nor EME-HEI-2 displayed strong affinity for adhering to established institutional quality regimes (following Lo, 2014; Mok, 2011). This weakness regarding operationalising institutional frameworks ultimately proved to be a major source of disharmony in the relationship with the AME-HEI. EME-HEI-1 and EME-HEI-2 displayed a lack of AME-style maturity and a behavioral legacy of operating in near-institutional void contexts (Anheier, 2014; Khanna, Palupu \& Bullock, 2010). Nevertheless, given that this was a predominant part of the EME-HEI mind-set, upon entering the AME setting this immaturity clearly operated as a 'strength' in favor of the EME firms but against the AME-HEI, which wanted the flexibility these EME-HEIs represented but demanded that it stay within established (exploitative-style) boundaries. The EME firms seemed to view explorative flexibility as a 'wild-card they could play' (within their predominant Constant reconfiguration /Commercial and Radical Modes) because the AME-HEI strongly, if quietly, desired these characteristics. For the AME-HEI, its staff believed relations would intra-exploitatively ameliorate as the collaboration with EME-HEIs progressed and that the EME-HEI would acculturate towards Elitist-Network and Measured-Collaborative modes within the robust institutional framework of the British AME arena. If any significant acculturation took place, it appears to have happened primarily at a superficial level and this is an important observation (and cautionary note) for aspirant collaborating AME-HEIs. This indicates the power of latent inter-explorative modes in EME-HE partners within these collaborations. The organisational reputational and legimisation exploitative dimensions of the AME-HEI context were valued by 
the EME-HEIs not as 'good' per se but rather as an inter-explorative 'promotional feature' by which to draw in more students and revenue. This illustrates an instance of what can be termed 'ethnocentric goal myopia' whereby both the AME-HEI and EME-HEI wantonly pursued their own objectives while, either though self-delusion, misrepresentation or culturally informed leadership styles, pretending that all was proceeding as expected. This overall EME-HEI explorative predilection towards certain behaviors in relation to AME institutional quality frameworks represents a major issue for such collaborations and is a factor that must be considered by AME-HEIs when undertaking partnerships.

While revenue streams and reverse innovation - access to attendance monitoring technology and student recruitment networks - were the key benefits originally promised to the AME-HEI, it is difficult to determine what lessons were actually gleaned in the longer run by the AME-HEI. Reputation was repeatedly jeopardised due to differing ambidextrous dispositional approaches between the partners. EME-HEI/AME-HEI collaborations offer attractive revenue streams but conceal costs such as reputational risk, opportunity costs on other worthwhile activities, or energies spent trying repeatedly to address quality issues generated by explorative-style EMEHEI postures. Furthermore, the EME institutions effectively appropriated the AME-HEI's exploitative legitimacy and reputational standing by offering approved academic programs from a historically reputable HEI. In this way, it simulates the mimetic isomorphic behaviors identified by DiMaggio and Powell (1983). Moreover, by seeking such mimetic effects the EME-HEIs used various forms of 'legitimacy': place legitimacy (the international student recruitment 'hot-spot' of London) and partner legitimacy (linking to a well-reputed UK HEI). A further form may also be considered to be product legitimacy. These legitimacies conferred 
reputational effects on the EME-HEIs because the firms were using AME-HEI high-value products rather than EME-originated programs. This effect offered greater brand status and thus demand from students seeking greater value for their investment. Thus, the acquisition of various forms of AME-linked legitimacy by EME-HEIs emerged as a key driver. EME firms seek this solidity for various motives at the same time as simultaneously maintaining ambidextrous explorative mind-sets and stances within the partnership. In other words, surrogate credentials are acquired, deployed, expended, and then put aside as the EME-HEI moves on to collaborate with another host to repeat the life-cycle of the arrangement. Overall, there were relatively few risks for the EME-HEI institutions because they had the ability to change partners and move between countries and markets readily. Thus, the explorative risk dimensions were carried primarily by the exploitative host AME-HEI as it risked reputational damage of the legacy of any partnership difficulties regarding quality, student visa queries, etc. The UK AME-HEI could neither separate itself from the national governmental quality and standards regime to which it is subject nor could it easily reinvent a historical legacy and tradition built up over decades or centuries. This represented a serious potential loss of reputational capital for the AME institution. In the case of the AME concerned its tentative ambidextrous explorative foray into 'myopic internationalization' partnership with an EME (which possessed differing sensemaking perspectives linked to mobility and high explorative ambidexterity) threatened its brand protection in a serious manner.

In summary, in contrast to the host AME-HEI, the mind-sets of the EME-HEI firms resided in a very different place of ambidextrous sensemaking (Birkinshaw \& Gibson, 2004; Weick, 2009) than their collaborative AME organisations, with a range of contextual drivers motivating EME- 
HEI actions. The study revealed a range of fluctuating shared and conflicting goals and ambidextrous behaviors, dispositions and modes within the collaborations and their impacts on the potential success of the relationship (following Ahammad, Tarba, Liu \& Glaister, 2014; Liu \& Woywode, 2013).

\section{Conclusions and Recommendations}

EME-HEI firms often emerge from regions with weak institutional fabric, and occasionally institutional voids, and this, combined with their relative youth tends to induce potent ambidextrous explorative postures. In contrast, AME-HEIs organisations often have strong exploitative operational bases and revenue streams in predominantly explorative AMEs and neighboring AMEs contexts. These are grounded in exploitatively-oriented environments strongly informed and underpinned by regulatory frameworks and well-established reputations and legitimacies. Consequently, collaborative encounters between AME-HEIs and EME-HEIs generate a complex set of ambidextrous dynamics and hitherto this has been under-explored in the literature and empirically. The present paper has developed an ambidextrous framework and generates data which seeks to address these lacunae. Importantly, the paper contributes an ambidextrous framework based on intra-exploitative/inter-exploitative and intraexplorative/inter-exploitative dimensions. These dimensions are applied to AME-HEI and EMEHEI contexts and the conceptual characteristics and issues associated with the various positions elaborated and explored. Furthermore, this theoretical development is subsequently extended through the engagement with a contribution of novel empirical case data from AME-HEI and EME-HEI collaborations. Within the developed overall ambidextrous framework, the data indicate a number of features and effects linked to the ambidextrous dynamics of the 
collaboration. These include issues surrounding, for example, explorative and exploitative attitudes to regulatory frameworks with AME-HEIs becoming increasingly frustrated at EMEHEI explorative behaviour in relation to rule boundaries. Moreover, varying AME-HEI and EME-HEI attitudes towards issues of reputation and legitimisation demonstrated the generally exploitative AME-HEI drift towards the phenomenon of 'explorative pull' whereby it is drawn away from its exploitative predilection to more unfamiliar and uncertain, indeed potentially dangerous and high-risk, explorative postures. For the EME-HEI, the opportunity to engage with exploitative contexts offers fresh, and significant, place, product and partner legitimacies potently connected to the lure of the AME market. Nevertheless, the argument also identified that the ambidextrous interface of the AME-HEI and EME-HEI also led to a series of promises to the AME-HEI which were ultimately unfulfilled by the EME-HEI.

Overall, this study has contributed novel granular and 'fine-grained' ambidextrous elaboration of the anatomy of AME-HEI and EME-HEI collaborations. This has thus far been absent from the literature and, given the size of the HE collaborative sector and market, the generation of such data, leading to heightened understanding in this domain is important. Building on findings and conclusions, from a theoretical perspective, this study supports the growing body of literature surrounding the importance of ambidextrous approaches within a global market (Birkinshaw \& Gupta, 2013; O’Reilly \& Tushman, 2004, 2008, 2011; Stokes et al., 2015).

In terms of recommendations, these are likely to be different for EME-HEIs and AME-HEIs and operate around the crux of the ambidextrous relationship tensions. For the AME-HEI, it is essential to ensure that an adequately resourced HE delivery base is available. This was a major 
unforeseen issue for the AME-HEI which mistakenly saw the EME-HEI collaborations as an easy and relatively inexpensive means to set up international operations. It is important for AME-HEIs not to underestimate the costs and extensive resource bases required when engaging with HEIs emanating from explorative EMEs. Inputs of greater amounts of human resource, rather than less, should be the byword in these HE collaborative contexts (indeed, this imperative for the application of additional human resources and human resource department expertise may also resonate with a wide range of international corporate collaborations beyond HE). Moreover, a detailed operational awareness and respect by the prospective EME-HEI partner of AME exploitative-style quality regimes and processes when operating in AME-HE contexts is required. This demands early elaboration of a clear strategy using the dispositional and modal typology, in the matrix presented in Table 1 to identify the nature of the proposed partner. Then, the mapping of a strategy across the matrix will allow the AME-HEI to traverse the exploitativeexplorative terrain. The AME must avoid 'explorative pull' and 'myopic internationalisation' effects. This may also require, for example, extensive recruitment of respective AME and EME nationals who are familiar with national systems, protocols, and cultures. Moreover, for AMEHEIs, due diligence on the proposed EME-HEI partner is critical. Management development on cultural awareness, expectations and potential project trajectories is also imperative.

\section{Limitations}

The study is based on a qualitative methodological approach which employed 21 semi-structured interviews within two EME case studies and the AME-HEI partner. Qualitative research aims understand the factors in particular case contexts. In this methodological approach, the possibility of developing wide-ranging survey-style data does not fall within the scope of such a 
study and the lessons learned need to be taken forward and tested in other contextual settings.

For the present study, there is potential to conduct complementary studies in other business sectors and national contexts.

\section{References}

Anteby, M., Lifshitz, H. \& Tushman, M. (2014) 'Using qualitative research for "how” questions', primer: qualitative research in strategic management, Strategic Management Journal [originally posted

September 2014; updated October 2014], http://strategicmanagement.net/pdfs/qualitative-research-instrategic-management.pdf.

Ahammad, M.F., Tarba, S.Y., Liu, Y., \& Glaister, K. (2014). Knowledge transfer and cross-border acquisition performance: Impact of cultural distance and employee retention. International Business Review. Advance online publication 15 July, doi:10.1016/j.ibusrev.2014.06.015.

Alajoutsijäryi, K., Juusola, K., \& Lamberg J.A. (2014). Institutional logic of business bubbles: Lessons from the Dubai business school mania. Academy of Management Learning and Education, 13(1):5-25.

Anheier, H. (2014). Institutional voids and the role of civil Society: the case of global finance. Global Policy, 5(1), 23-35.

Anwar, S.T. (2015). Super-connectors: A new model of internationalization from the MENA region. Thunderbird International Business Review, 57(2), 163-180.

Azmat, F., \& Ha, H. (2013). Corporate social responsibility, customer trust, and loyalty - Perspectives from a developing country. Thunderbird International Business Review, 55(3), 253-270.

Beamish, P.W., \& Lupton, N.C. (2015). Cooperative strategies in international business and management: Reflections on the past 50 years and future directions. Journal of World Business. doi:

10.1016/j.jwb.2015.08.013

Birkinshaw, J., \& Gibson, C. (2004). Building ambidexterity into an organization. Sloan Management Review, 45(4), 47-55.

Birkinshaw, J., \& Gupta, K. (2013). Clarifying the distinctive contribution of ambidexterity to the field of organization studies. Academy of Management Perspectives, 27(4), 287-298.

Bogdan, R.C. \& Biklen, S. (2007). Qualitative Research for Education: An Introduction to Theories and Methods. London: Pearson.

Buckley, P.J., Elia, S., \& Kafouros, M. (2014). Acquisitions by emerging market multinationals: Implications for firm performance. Journal of World Business, 49(4), October, 611-632.

Chakrabarty, S., \& Bass, A.E. (2013). Encouraging entrepreneurship: Microfinance, knowledge support, and the costs of operating in institutional voids. Thunderbird International Business Review, 55(5), 545562. 
Department of Business, Innovation and Skills (BIS-UK). (2013). International Education: Global Growth and Prosperity. London: BIS-UK. Available at: https://www.gov.uk/government/ uploads/system/uploads/attachment_data/file/340600/bis-13-1081-international-education-global-growthand-prosperity-revised.pdf (Access date?)

DiMaggio, P.J., \& Powell, W.W. (1983). The iron cage revisited: Institutional isomorphism and collective rationality in organisational fields. American Sociological Review, 48(2), 147-160.

Economist (The). (2011). A new kind of global company is on the rise: diversified multinationals from emerging markets. March 3, 2011.

Edmondson, A., \& McManus. (2007) Methodological fit in management field research, Academy of Management Review, 32(4): 1155-1179.

Eisenhardt, K.M., \& Graebner, M.E. 2007. Theory building from cases: Opportunities and challenges. Academy of Management Journal, 50(1): 25-32.

Ennew, C. \& Greenway, D. (2012). Globalization of Higher Education. Hampshire: Palgrave Macmillan.

Gibbert, M., Ruigrok, W., \& Wicki, B. (2008). What passes as a rigorous case study? Strategic Management Journal, 29(13), 1465-1474.

Govindarajan, V., \& Trimble, C. (2013). Reverse innovation: Create far from home, win everywhere. Boston: Harvard Business Press.

Guillotin, B., \& Mangematin, V. (2015). Internationalization strategies of business schools: How flat is the world? Thunderbird International Business Review, 57(5), 343-357.

Hansen, A., \& Wethal, U. (2014). Emerging Economies and Challenges to Sustainability: Theories, Strategies, Local Realities. Abingdon, UK: Routledge.

Higher Education Funding Council of England (HEFCE) (2015). (retrieved from http://www.hefce.ac.uk/about/ on 22/01/2015).

HM Government (2013). International Education: Global Growth and Prosperity. Available at https://www.gov.uk/government/uploads/system/uploads/attachment_data/file/340600/bis-13-1081international-education-global-growth-and-prosperity-revised.pdf. Accessed on 5/11/2014.

Holtbrïgge, D., \& Baron, A. (2013). Market Entry Strategies in Emerging Markets: An Institutional Study in the BRIC Countries. Thunderbird International Business Review, 55(3), 237-252.

Jayaram, J., \& Avittathur, B. (2015). Green supply chains: A perspective from an emerging economy. International Journal of Production Economics, 164, 234-244.

Junni, P., Sarala, R.M., Taras, V., \& Tarba, S.Y. (2013). Organizational ambidexterity and performance: A meta-analysis. Academy of Management Perspectives, 27(4), 299-312.

Junni, P., Sarala, R., Tarba, S.Y., Liu, Y., and Cooper, C. (2015). The role of human resources and organizational factors in ambidexterity. Human Resource Management, 54 (S1), 1-28. 
Kedia, B.L., Rhew, N.D., Gaffney, N.T., \& Clampit, J.A. (2015). Emerging market multinationals: Coopetition for global growth. Thunderbird International Business Review.

Khanna, T., Palepu, K., \& Bullock, R. (2010). Winning in emerging markets: A road map for strategy and execution. Boston: Harvard Business Press.

King, N., \& Horrocks, C. (2010). Interviews in Qualitative Research, London: Sage Publications

Kirkpatrick, C., Lee, N., \& Nixson, F. (2010). Industrial structure and policy in less developed countries. London: Routledge.

Lawrence, T., Suddaby, R., \& Leca, B. (2011). Institutional work: Refocusing institutional studies of organization. Journal of Management Inquiry, 20(1), 52-58.

Li, B., Kumar, M., \& Von Glinow, M.A. (2015). Learning from the globalization of an emerging economy firm: Are current internationalization theories relevant? In M. Marinov,(2015) ed. Experiences of Emerging Economy Firms. Basingstoke, UK: Palgrave Macmillan, 170-203.

Lo, W.Y.W. (2014). Think global, think local: The changing landscape of higher education and the role of quality assurance in Singapore. Policy and Society, 33(3), 263-273.

Londonhigher (2015). The Economic Impact of International Students to London's Economy: A Quantitative Perspective. Final Report. Available at: http://www.londonhigher.ac.uk/fileadmin/ documents/Publications_2015/StudyLondon_EconomicAnalysis_2011.pdf. Accessed on: 18 November 2015

Liu, Y. (2011). High-tech ventures' innovation and influences of institutional voids: A comparative study of two high-tech parks in China, Journal of Chinese Entrepreneurship 3 (2), 112-133.

Liu, Y., \& Almor, T. (2014). How culture influences the way entrepreneurs deal with uncertainty in interorganizational relationships: The case of returnee versus local entrepreneurs in China. International Business Review. doi: 10.1016/j.ibusrev.2014.11.002

Liu, Y., \& Woywode, M. (2013). Light-touch integration of Chinese cross-border M\&A: The influences of culture and absorptive capacity. Thunderbird International Business Review, 55(4), 469-483.

Lumby, J., \& Foskett, N. (2015). Internationalization and Culture in Higher Education. Educational Management Administration \& Leadership. doi: 10.1177/1741143214549978.

McAdam, R., Keogh, W., El Tigani, A.A. \& Gardiner, P. (2013). An exploratory study of business excellence implementation in the United Arab Emirates (UAE) public sector: Management and employee perceptions. International Journal of Quality \& Reliability Management, 30(4), 426-445.

Marginson, S. \& Wende, M.V.D. (2007). Globalisation and higher education. Paris: Organization for Economic Cooperation and Development.

Meglio, O., King, D.R., \& Risberg, A. (2015). Improving acquisition outcomes with contextual ambidexterity. Human Resource Management. doi:10.1002/hrm.21721

Mok, K.H. (2011). The quest for regional hub of education: Growing heterarchies, organizational hybridization, and new governance in Singapore and Malaysia. Journal of Education Policy, 26(1), 61-81. 
Mordi, C., Mmieh, F. \& Ojo, S.L. (2013). An exploratory study of managers' perspective of work-life balance in Nigeria: a case analysis of the Nigerian banking sector. Thunderbird International Business Review, 55(1): 55-75.

Morley, L., Marginson, S. \& Blackmore, J. (2014). Education and neoliberal globalization. British Journal of Sociology of Education, 35(3), 457-468.

Nwankwo, S. (2012). Renascent Africa: Rescoping the landscape of international business. Thunderbird International Business Review, 54(4), 405-409.

O’Reilly, C. A., III, \& Tushman, M. L. (2004). The ambidextrous organisation. Harvard Business Review, 82(4), 74-81.

O'Reilly, C. A., III, \& Tushman, M. L. (2008). Ambidexterity as a dynamic capability: Resolving the innovator's dilemma. Research in Organisational Behavior, 28, 185-206.

O'Reilly, C. A., III, \& Tushman, M. L. (2011). Organisational ambidexterity in action: How managers explore and exploit. California Management Review, 53(4), 5-22.

O’Reilly, C. A., III, \& Tushman, M. L. (2013). Organizational ambidexterity: Past, present and future. Academy of Management Perspectives, 27(4), 324-338.

OECD. (2015). Education at a Glance 2014: OECD Indicators. OECD Publishing. Retrieved from http://www.oecd.org/edu/eag.htm. Accessed on 22/01/2015.

Philpott, K., Dooley, L., O'Reilly, C., \& Lupton, G. (2011). The entrepreneurial university: Examining the underlying academic tensions. Technovation, 31(4): 161-170.

Polonsky, M.J. \& Waller, D.S. (2005) Designing and Managing a Research Project: A Business Students Guide. London, Sage Publishing.

Porter, M.E. (2008). The Five Competitive Forces That Shape Strategy. Harvard Business Review, 86(1), 78-93.

Raisch, S. \& Birkinshaw, J. (2008). Organizational ambidexterity: Antecedents, outcomes, and moderators. Journal of Management, 34(3) 375-409.

Raisch, S., Birkinshaw, J., Probst, G., \& Tushman, M.L. (2009). Organizational ambidexterity: Balancing exploitation and exploration for sustained performance. Organization Science, 20(4), 685-695.

Saldanha, J., Mello, J.E., Knemeyer, A.M. \& Vijayaraghavan, T.A.S. (2014). Implementing supply chain technologies in emerging markets: An institutional theory perspective. Journal of Supply Chain Management, 51(1), 5-26.

Sartor, M. A. \& Beamish, P. W. (2014). Offshoring innovation to emerging markets: Organisational control and informal institutional distance. Journal of International Business Studies, 45, 1072-1095.

Shiel, C. (2008). Introduction. In Atfield, R. \& Kemp, P. (Eds). Enhancing the international learning experience in business and management, Hospitality, Leisure, Sport, and Tourism. Newbury, UK:

Threshold Press. 
Siggelkow, N. (2007). Persuasion with case studies. Academy of Management Journal, 50(1), 20-24.

Simsek, Z. (2009). Organizational ambidexterity: Towards a multilevel understanding. Journal of Management Studies, 46(4), 59-624.

Slaughter, S. \& Cantwell, B. (2012). Transatlantic moves to the market: The United States and the European Union. Higher Education, 63(5), 583-606.

Stake, R.E. (2008). Qualitative Case Studies. In Denzin, N.K. \& Lincoln, Y.S. (Eds.), Strategies of Qualitative Inquiry. $3^{\text {rd }}$ ed. London: Sage, 119-149.

Stokes, P., Moore, N., Moss, D., Mathews, M., Smith, S.M., \& Liu, Y. (2015). The micro-dynamics of intraorganizational and individual behavior and their role in organizational ambidexterity boundaries. Human Resource Management, doi: 10.1002/hrm.21690.

Study London. (2015). Why Study in London? Retrieved from: http://www.studylondon.ac.uk/whystudy-in-london/. Accessed on 23/01/2015.

Suddaby, R., Foster, W.M., \& Mills, A.J. (2014). Historical institutionalism. In M. Buceli \& R. Daniel Wadhwani (Eds). Organizations in time: History, theory, methods. Oxford: Oxford University Press, 100123.

Teagarden, M.B. (2013). Not all emerging markets are created equal. Thunderbird International Business Review, 55(3), 235-236.

Theodorakopoulos, N. \& Figueira, C. (2012). What can situated learning theory tell us about leading to develop organizational learning capabilities for entrepreneurial performance? Lessons from a knowledgeintensive small firm. Thunderbird International Business Review, 54(6): 859-873.

UKCISA (2015). International Student Statistics: UK Higher Education. Available at: http://www.ukcisa.org.uk/Info-for-universities-colleges--schools/Policy-research--statistics/Research-statistics/International-students-in-UK-HE/\#International-student-numbers-by-UK-nation-and-Englishregions-2013-14. Accessed on: 18 November 2015.

Universities UK (2014). The Impact of Universities on the UK Economy. Retrieved from: http://www.universitiesuk.ac.uk/highereducation/Documents/2014/TheImpactOfUniversitiesOnTheUkEc onomy.pdf. Accessed on 22/01/15.

Walker, P. (2015). The globalisation of higher education and the sojourner academic: Insights into challenges experienced by newly appointed international academic staff in a UK university. Journal of Research in International Education, 14(1), 61-74.

Weber, Y., Tarba, S. Y., \& Öberg, C. (2014). A comprehensive guide to mergers \& acquisitions: Managing the critical success factors across every stage of the M\&A process. Upper Saddle River, NJ: Pearson \& Financial Times Press.

Webster, A., \& Dunning, J. H. (2013). Structural Change in the World Economy (Routledge Revivals). London: Routledge. 
Weick, K. (2009). Making Sense of the Organisation: Volume 2 - the Impermanent Organisation, London: John Wiley and Sons.

Welfens, P.J. (Ed.). (2013). Economic aspects of German unification: national and international perspectives. Springer Science \& Business Media.

Wolfe, J. \& Chasser, A. (2012). Domain Names Rewired: Strategies for Brand Protection in the Next Generation of the Internet. London: John Wiley \& Sons.

Xia, J., Ma, X., Lu, J. W., \& Yiu, D. W. (2014). Outward foreign direct investment by emerging market firms: A resource dependence logic. Strategic Management Journal, 35(9), 1343-1363.

Xing, Y., Liu, Y., Tarba, S.Y., \& Cooper, C.L. (2014). Intercultural influences on managing African employees of Chinese firms in Africa: Chinese managers' HRM practices. International Business Review, doi: 10.1016/j.ibusrev.2014.05.003.

Xing, Y., Liu, Y., Tarba, S. Y., \& Wood, G. (2016). A cultural inquiry into ambidexterity in supervisorsubordinate relationship. The International Journal of Human Resource Management, Published online: 16 Mar 2016, 1-20. doi: DOI:10.1080/09585192.2015.1137619

Yang, W., \& Meyer, K. E. (2015). Competitive dynamics in an emerging economy: Competitive pressures, resources, and the speed of action. Journal of Business Research, 68(6), 1176-1185.

Yin, R.K. (2009). Case Study Research: Design and Methods, $4^{\text {th }}$ ed., Thousand Oaks, CA: Sage.

Table 2: Summative profiles of the two EME-HE organisations

\begin{tabular}{|l|c|c|}
\hline Case Study Organisations & EME-HE-1 & EME-HE-2 \\
\hline Country of Origin & Indonesia & Vietnam \\
\hline Year established in EME & 1985 & 1991 \\
\hline Year of entry into the UK & 2002 & 2003 \\
\hline $\begin{array}{l}\text { Number of students outside } \\
\text { of the UK }\end{array}$ & 16,320 & 230 \\
\hline $\begin{array}{l}\text { Number of students in the } \\
\text { UK }\end{array}$ & 1650 & 2 \\
\hline $\begin{array}{l}\text { Number of UK HEI } \\
\text { partnerships }\end{array}$ & 3 & 250 \\
\hline Key Challenges & $\begin{array}{l}\text { - Maintenance of recruitment } \\
\text { levels; }\end{array}$ & $\begin{array}{l}\text { - Compliance with regulatory } \\
\text { requirements due to legacy of }\end{array}$ \\
\hline
\end{tabular}




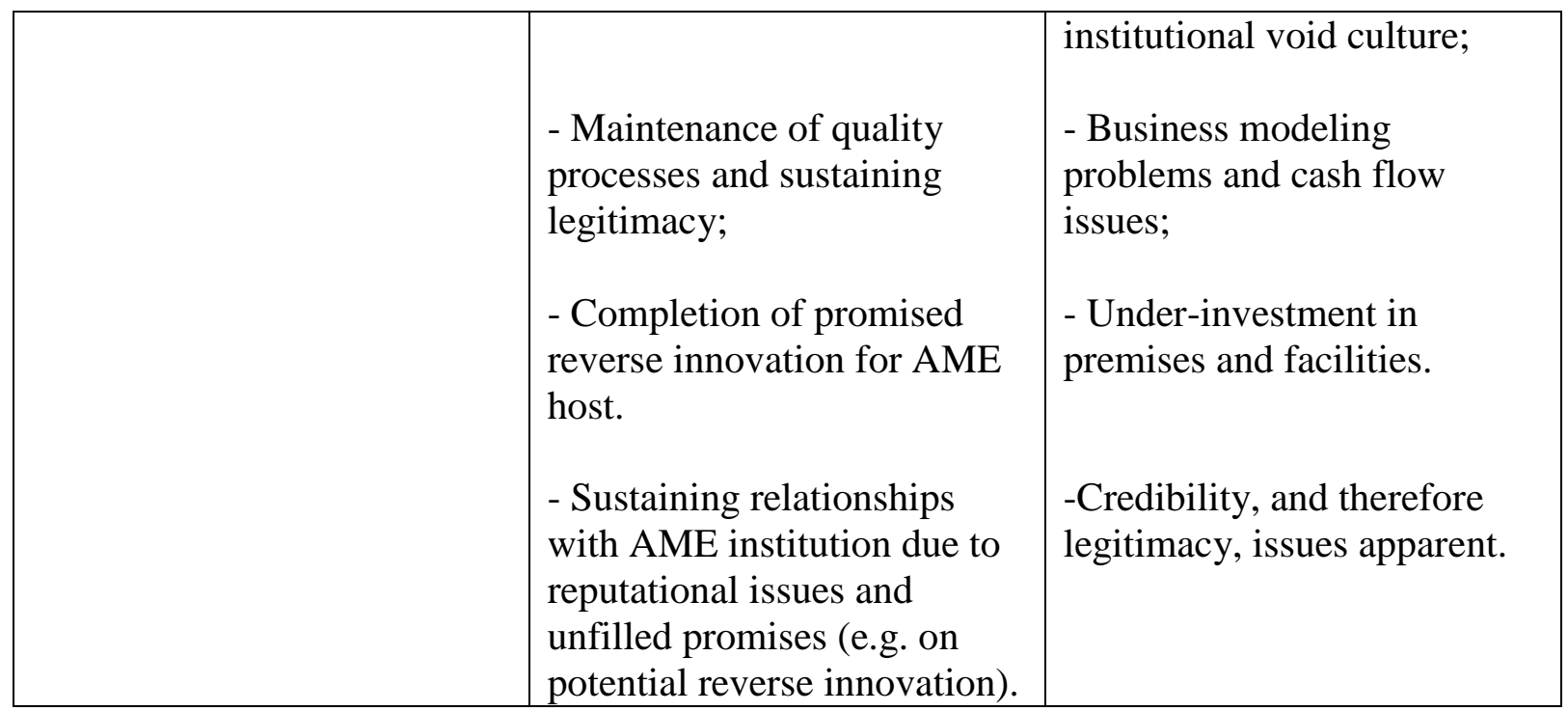


Table 3 - Data collection interviewee summary

\begin{tabular}{|c|c|c|}
\hline \multicolumn{3}{|l|}{ Case Study - EME-HEI-1 } \\
\hline Role & Profile & Location \\
\hline Marketing Director & Male SE Asian & Indonesia \\
\hline Academic Quality Director & Male (European) & UK \\
\hline Student Experience Co-ordinator & Female SE Asian & UK \\
\hline Professor 1 & Male British & UK \\
\hline Professor 2 & Male British & UK \\
\hline Professor 3 & Female SE Asian & UK \\
\hline Professor 4 & Female SE Asian & Indonesia/UK \\
\hline Professor 5 & Male SE Asian & Indonesia/UK \\
\hline \multicolumn{3}{|l|}{ Case Study - EME-HEI-2 } \\
\hline $\begin{array}{r}\text { Role } \\
\end{array}$ & Profile & Location \\
\hline Owner- Director & Male SE Asian & Vietnam \\
\hline Shareholder & Male (European) & UK \\
\hline Marketing Manager & Female (British) & UK \\
\hline Academic Quality Co-ordinator & Male (SE Asian) & UK \\
\hline Business Manager & British Manager & Vietnam \\
\hline Professor 1 & Female British & UK \\
\hline Professor 2 & Female British & UK \\
\hline Professor 3 & Female SE Asian & UK \\
\hline Professor 4 & Female SE Asian & Vietnam/UK \\
\hline \multicolumn{3}{|l|}{ Case Study AME-HEI Partner } \\
\hline Role & Profile & Location \\
\hline Quality Director & Male British & UK \\
\hline Business Manager & Female British & UK \\
\hline Lead Academic & Male British & UK \\
\hline Liaison Director & Female British & UK \\
\hline
\end{tabular}


Table 4: Indicative Summary of Coding Data

\begin{tabular}{|c|c|}
\hline A priori codes & Segments \\
\hline \multicolumn{2}{|c|}{ Attitudes to Regulatory Frameworks } \\
\hline & $\begin{array}{l}\text { Flexible approach } \\
\text { (Revelatory of risk-taking, explorative attitudes) }\end{array}$ \\
\hline & $\begin{array}{l}\text { Stringent Approach } \\
\text { (Revelatory of caution and risk-aversion, exploitative } \\
\text { attitudes) }\end{array}$ \\
\hline \multicolumn{2}{|c|}{$\begin{array}{l}\text { Organisational Reputation and } \\
\text { legitimisation }\end{array}$} \\
\hline & $\begin{array}{l}\text { AME-HEls mindful of protecting reputation } \\
\text { (displaying ambidextrous exploitative tendencies) }\end{array}$ \\
\hline & $\begin{array}{l}\text { EME-HEls seeking to acquire, glean and build reputation } \\
\text { (by surrogate means if required) }\end{array}$ \\
\hline & $\begin{array}{l}\text { Place legitimisation } \\
\text { (variously working for AME-HEls and EME-HEIs) }\end{array}$ \\
\hline & $\begin{array}{l}\text { Partner legitimisation } \\
\text { (working primarily for EME-HEls vis-à-vis AME-HEIs) }\end{array}$ \\
\hline & $\begin{array}{l}\text { Product legitimisation } \\
\text { (working primarily for EME-HEIs vis-à-vis AME-HEIs) }\end{array}$ \\
\hline \multicolumn{2}{|c|}{ Unfulfilled Promises and Expectations } \\
\hline & Unachieved Reverse Innovation (for AME-HEI) \\
\hline & Unachieved revenue streams (for AME-HEI) \\
\hline \multicolumn{2}{|c|}{ Mis-Matching of Resources } \\
\hline & $\begin{array}{l}\text { AME-HEI under-resourcing of EME-HEI collaborative } \\
\text { initiatives by its normative standards } \\
\text { (potentially due to inexperience in internationalisation) }\end{array}$ \\
\hline & $\begin{array}{l}\text { EME-HEI under-resourcing of collaborations with AME- } \\
\text { HEIs due to explorative and flexible posture and weak } \\
\text { connectivity with regulatory frameworks }\end{array}$ \\
\hline \multicolumn{2}{|l|}{ Explorative Pull } \\
\hline & $\begin{array}{l}\text { AME-HEIs drawn towards collaboration with EME-HEls } \\
\text { and EME environments }\end{array}$ \\
\hline \multicolumn{2}{|c|}{ Metropolitan Pull } \\
\hline & $\begin{array}{l}\text { EME-HEls drawn to London } \\
\text { (to seek place, partner and product legitimisation, } \\
\text { revenue) }\end{array}$ \\
\hline \multicolumn{2}{|c|}{ AME management Imperatives } \\
\hline & To have 'Success' \\
\hline & Reverse Innovation \\
\hline & Revenue streams \\
\hline \multicolumn{2}{|c|}{ Ethnocentric Goal Myopia } \\
\hline & AME-HEI seeking international networks and revenue \\
\hline & EME-HEI seeking legitimisation and revenue \\
\hline & $\begin{array}{l}\text { Myopic Internationalisation } \\
\text { (predominantly AME-HEI) }\end{array}$ \\
\hline
\end{tabular}

